\title{
Agricultural Credit and Economic Growth in Nigeria
}

\author{
Adesanya, Teniola Abosede \& Ajala, Olufunmilayo Adekemi \\ Department of Banking and Finance, \\ The Polytechnic, Ibadan, \\ Oyo State, \\ Nigeria. \\ Email: Tennytone@Yahoo.Com \\ Email: adekemiajala@gmail.com \\ Phone: +2348033752838, +2348034335938
}

\begin{abstract}
The Agricultural sector is highly indispensable to growth of any nation. It has been the source of feeding of the populace, raw material for industries and income generation for other developmental activities. Various governments have been made efforts to improve economic growth and agricultural productivity through agricultural credit but rarely one can see any improvement in the sector. It is in line with these fundamental role that this study makes a giant stride to examine the impact of agricultural credit on Nigeria's economic growth . The study employs time series data from publications of Central Bank of Nigeria, Statistical Bulletin, National Bureau of Statistics and internet publication of policy issues on agriculture in Nigeria which spanned from 1985-2016. This study employs the three stage least square analysis as the estimation technique to investigate the variables. The findings shows that agricultural credit is an effective instrument for counter-cyclical agricultural output, non-oil export and GDP stabilization in the Nigerian economy although the value of GDP fell at the end of the period indicating that, such policies deteriorate with time. The study concludes that agricultural credit, interest rate exchange rates were all important in affecting aggregate output in Nigeria. The study recommends that agricultural credits should be extended for development of agricultural production because it has causality effect on economic growth.
\end{abstract}

Keywords: Agricultural Credit And Economic Growth

Journal Reference Format:

Adesanya, T.A. \& Ajala, O.A. (2018): Agricultural Credit and Economic Growth in Nigeria

Humanities, Management, Arts, Education \& the Social Sciences Journal. Vol. 7 . No.1, Pp 11-20

Article DOI: dx.doi.org/10.22624/AIMS/HUMANITIES/V7N1P2

Available online at www.humanitiesjournal.org

\section{INTRODUCTION}

Agriculture is an important sector that played a crucial role in the growth process of Nigeria's economy at present as price of crude oil fall at international market. In the time past, crude oil and gas exports accounted for more than $98 \%$ of export earnings and about $83 \%$ of federal government revenue (Odularo, 2008). Contrast to agricultural exploration in Nigeria, the National Bureau of Statistics (NBS) stated that oil production was at 2.1 million barrel per day at the first quarter of 2016 while the oil sector contributed $10.29 \%$ of total real GDP. 
This has made oil to be area of focus for a long time. Recently, the Nigerian government has continue to renew their commitments to diversify into agricultural sector as the price of oil in the international market continue to drop and countries in OECD has made a declaration to invest in green energy. In Nigeria, agriculture involves crop production, livestock, forestry and fishing. It remains the highest contributor to the GDP with an average of 40.1 percent over the entire period. Agricultural sector was followed closely by the services sector with a combined contribution of 38.1per cent, out of which the private services sub-sector accounted for about 29.0 percent. Over the years, agriculture provides employment opportunities, provision of goods and services, contribution to government revenue and energy supply.

Credit facilities to agriculture are the provision of working capital loans for farm businesses. The scheme aims at fast tracking development of the agricultural sector of the Nigerian economy by providing credit facilities to commercial agricultural enterprises at a single digit interest rate; Enhance national food security by increasing food supply and effecting lower agricultural produce and product prices, thereby promoting low food inflation; Reduce the cost of credit in agricultural production to enable farmers exploit the potentials of the sector and Increase output, generate employment, diversify the revenue base, increase foreign exchange earnings and provide input for the industrial sector on a sustainable basis. The fewer available schemes in Nigeria are: Agricultural Development Trust Fund Credit (ADTFC) and Guaranteed Fund Credits.

Over time, arguments have ensue in the literature that agricultural sector is under funding and credits are not given to the farmers which is creating growth drag to economic development. For instance, Adediran and Obasan (2010) have argued that in developing countries (of which Nigeria is inclusive), productivity growth tends to be higher in agriculture than manufacturing, but in terms of output growth manufacturing continues to outperform agriculture. The manufacturing sector offers more opportunities for capital accumulation than the agricultural sector since it is more spatially concentrated than the agricultural sector which is spatially dispersed. Nevertheless, many years of neglect and maladministration on the part of successive military and civilian governments, coupled with corruption and indiscriminate policy reversals, have rendered agriculture sectors a comatose.

In addition, factors such as education (Pudasaini, 1983), infrastructure (Queiroz \& Gautam, 1992; Gopinath \& Roe, 1997; Yee et al., 2002), and inflation (Bullard \& Keating, 1995; Andrés \& Hernando, 1997; Gokal \& Hanif, 2004) have also led to the poor performance of the sector. Other factors include lack of modern inputs and credit facilities (Iganiga \& Unemhilin, 2011; Awe, 2013; Zakaree, 2014), land and environmental degradation, inadequate research and extension services (Olajide et al., 2012). Among these factors, the lack of insufficient fund and credit facilities seems to be the core issue facing agriculture as other matters are directly and indirectly linked to it. For instance, most farmers in the rural areas are faced with the challenges of accessing formal credit that has resulted in the dominance of informal credit associations such as credit and drift cooperatives, and money lenders.

Farmers in the rural areas find it difficult in accessing formal credit because the financial institutions, which suppose to provide formal financial credits, are controlled from headquarters located in the cities, hence, cannot adequately cater for the need of subsistence farmers (Obeta, 1992). Furthermore, the complicated procedures involved in securing loans coupled with the high-interest rates charges, have restricted the access of farmers to fund in the sector. Consequence upon these, it has become pertinent to evolve means of stimulating the availability of credit in the sector. More so, agriculture sector, however, is still spring from a number of inherent and apparent problems. 
Water logging/salinity coupled with scarcity of irrigation water rank at the top of physical problem while weak marketing mechanism and ineffective cooperative structure are prominent inherent problems. Keeping in view the population growth rate of 2 percent per annum, the need is to provide them a balance diet and limitation on expansion of cropped area, the national commission on agriculture has recognized for considerable expansion in the pace of agricultural production. Recent revaluating in agriculture has made it capital intensive but majority of our small farmers are not in position to practice agriculture on modern lines due to lack of capital.

The agriculture growth depends very much on improvement of infrastructural facilities, supply of enhanced irrigation water, land reclamation, transpiration, mechanical power and other critical form inputs like seeds, pesticides and fertilizers etc. Agricultural credit assumes even a central position in the whole strategy of agricultural development of a country like Nigeria for a number of reasons. Farming requires capital like other business for its farm operations. Timely availability of capital leads to adoption of improved seeds, fertilizers and modern technologies which increase the farm production and ultimately the growth rate. Therefore, agriculture credit is an essential element for modernization in agriculture. Therefore, the following research question is pertinent to this study. What is the impact of agricultural credit to economic development in Nigeria? How has agric credit affected agricultural development? This study aims at examine the determinants of agricultural credit on economic development.

\subsection{Brief Background of Agricultural Development in Nigeria}

In the 1960s, Nigerian economy was majorly driven by the agricultural sector accounting for about 70 percent of the country's Gross Domestic Products (GDP) and 65-70 percent of the nation's exports (Olajide, Akinlabi, \& Tijani, 2012). The sector has also contributed about 65 percent of employment to the teeming population and accounted for over 90 percent of the total food consumption requirement, thus, contributing significantly to the nation's food security (Emeka, 2007; Izuchukwu, 2011). Consequently, the agricultural sector was estimated to be the largest contributor to Nigeria's non-oil foreign earnings (Iganiga \& Unemhilin, 2011). The sector was also seen as the key to the development of the economy through product contribution, market contribution, factor contribution, and foreign exchange contribution (Abayomi, 1997). In recent time, the performance of the agricultural sector and its share of contributions to the nation's GDP have drastically reduced following the oil booms of the late 1970s that led to the neglect of agriculture (Olajide et al., 2012).

\subsection{Trend Analysis of Agricultural Credit in Nigeria}

In an attempt to ensure the availability of agricultural credit as a mean of providing the needed capital in the sector, the Federal government introduced agricultural credit institutions as well as policies and programmes. Some of these agricultural credit schemes include Nigerian Agricultural and Cooperative Bank (NACB), Agricultural Credit Guarantee Scheme Fund (ACGSF), Commercial Agricultural Credit Scheme (CACS), and Nigerian Incentive-based Risk Sharing for Agricultural Lending (NIRSAL). NACB was established in 1973 to provide medium and long-term credit to expand agricultural production. The bank was set up to tackle the challenges of low savings, inadequate investment, and lack of entrepreneurial skills in the sector. However, the inability of the NACB in actualizing the purpose of its establishment led to the creation of the Nigerian Agricultural, Cooperative and Rural Development Bank (NACRDB) in 2000 following the merger of NACB, the People Bank of Nigeria (PBN), and the Family Economic Advancement Programme (FEAP). 
The Agricultural Credit Guarantee Scheme Fund (ACGSF) was set up by the Federal Military Government in 1977 with the initial fund of N100 million to provide guarantee in respect of loans granted by banks for agricultural purposes that are connected with the establishment or management of plantation for the production of producing rubber, cocoa, oil palm tea, coffee and similar crops. The scheme, which is managed by the Central Bank of Nigeria (CBN) and a constituted Board, aims at increasing the volume of bank credit to the agricultural sector. The CACS was established in 2009 by the CBN in collaboration with the Federal Ministry of Agriculture and Water Resources to contribute to the development of agricultural sector via the expansion of lending by commercial banks to the sector. The purpose of the scheme is to induce the commercial banks to increase their lending for the development of commercial agriculture. In a bid to achieve this, the Federal Government raised a seven-year bond of N200 billion as intervention fund through the Debt Management Office and made the fund available to the sector through some approved commercial banks (Olomola \& Yaro, 2015).

The aim of the fund was to make credit facilities available for commercial agricultural enterprises at the single-interest rate. The government also introduced NIRSAL in 2011 to address the challenge of poor agricultural financing. The scheme focused on the development of value chain on six commodities namely cotton, tomato, maize, rice, cassava, and soybean. NIRSAL, unlike another scheme, encourages lending to all value chain actors and all categories of producers such as small, medium and large scale. NIRSAL is wholly financed by the CBN, which is also charged with the responsibility of enabling banks to lend with confidence. CBN also offers technical support and incentive to banks to reduce risk in lending. Despite the enormous resources committed to the agricultural sector by the Federal Government through the various formal credit institutions, schemes, policies, and programmes, the performance of the sector is still below average as the sector cannot supply domestic food requirement, raw materials for agro-allied industries, and generate enough foreign exchange via exports (Izuchukwu, 2011; Awe, 2013; Olomola \& Yaro, 2015). The sector remains undercapitalized; most farmers are unable to secure the equity capital required for expansion of operations and modernization of their enterprises, while the phobia among banks in lending to the sector is still in existence, despite the policy initiatives to address the situation (Olomola \& Yaro, 2015).

\section{BRIEF LITERATURE REVIEW}

Agricultural credit and economic development has been discussed in the literature. Studies of related nature show the relationship between credit supply and agricultural production, but there studies are still ongoing in the literature regarding the existence and direction of the relationship between these variables. Ammani (2012) investigated the relationship between agricultural production and formal credit supply in Nigeria using simple regression model and found that formal credit had a positive and significant impact on agricultural productivity. The study is important as it revealed the impact of formal credit to each of the agricultural sub-sectors (i.e. crops, livestock, and fishing). However, the major weakness of the study was the assumption that the source of the loan to the agricultural sector was mainly through agricultural credit guarantee scheme fund (ACGSF). The assumption is quite weak as there are specialized institutions, including commercial banks and other schemes, through which credit could be sourced by farmers. Awe (2013) examined the mobilization of domestic financial resources for agricultural productivity in Nigeria. Some of the financial resources the study identified include credit facilities from Nigerian Bank for Commerce and Industries (NBCI) and credit provided by commercial and merchant banks. The results revealed that these resources have a positive relationship with agricultural productivity in Nigeria. 
However, Ayegba \& Ikani (2013) assessment of agricultural credit on rural farmers in Nigeria through the administration of questionnaires found that credits to agriculture have not sufficiently boost productivity in the sector. Zakaree (2014) study on the impact of agricultural credit guarantee scheme fund (ACGSF) on domestic food supply in Nigeria using the ordinarily least square approach revealed that the credit scheme had a positive and significant impact on domestic food supply. On the contrary, Akinleye, Akanni, \& Oladoja (2005) appraisal of the agricultural credit guarantee scheme in Nigeria found that the scheme has failed in bringing about the desired productivity of the agricultural sector. Tasie \& Offor (2013) explored the effects of international fund for agricultural development (IFAD) credit supply on rural farmers in River state, Nigeria through the administration of questionnaires. The result showed that the IFAD credit programme has contributed significantly to farm output and income.

In the same vein, Chisasa \& Makina (2015) recent study on bank credit and agricultural output in South Africa using cointegration and error correction model (ECM) showed that credit supply has a positive and significant impact on agricultural output in the long run. However, the ECM revealed that bank credit has a negative impact on agricultural out in the short run. Olagunju \& Babatunde (2011) examined the impact of credit on poultry productivity in South-Western Nigeria through the administration of questionnaires. The outcome of the study showed that credit acquisition by farmers had led to increased productivity of poultry. Also, Adetiloye (2012) study on agricultural financing in Nigeria found that credit to the agricultural sector is significant but noted that credit supply has not been growing in relation to the economy. Khan et al. (2011) carried out a review of past literature on agriculture credit in the rural area of Pakistan. Their research findings clearly indicated that the importance of agriculture credit as not only developing the farming but also furnished every sector of the economy positively.

Hussain \& Taqi (2014) investigated the impact of agricultural credit on agricultural productivity in Pakistan using logit regression analysis. The results showed that there was a direct and significant relationship between credit and agricultural productivity. In the same vein, ur Rahman et al. (2014) investigated the impact of agricultural credit on agricultural productivity in Pakistan: an empirical analysis by using logit regression analysis. The outcome of their research findings shows that there exist a direct relationship between agricultural credit and agricultural productivity. Ahmad (2007) noted in his study that boosting agricultural productivity depends on the availability and accessibility of credit facility by farmers in respective of their areas. de Castro et al. (2012) study examine the rural credit and agricultural supply in Brazil within the period 1976-2005. The result of their research findings revealed that farmers normally have a budget constraint to purchase agricultural inputs (fertilizers, labour, pesticides, etc.), and government credit program might increase agricultural supply. 


\section{METHODS}

\subsection{Data Sources}

The data source for this study include publication from Central Bank of Nigeria (CBN) various issues, of annual report and statement of account and statistical bulletin; National bureau of statistics various issues and internet publication of policy issues on agriculture in Nigeria. 1988 broad based agricultural policies in Nigeria. The data from this period present a considerable degree of freedom that is necessary to capture the net effect of explanatory variables on the dependent variables. The data spans the period 1986 to 2015 .

\subsection{Theoretical Framework}

Chidi, (2008) and Marc, (2006) observed that countries at the early stages of development depend almost fully on agricultural growth for employment, foreign exchange, government revenue and food supply to the teemed population. In this sense, agricultural growth is the key driver of the growth of non-oil export in most countries of Sub-Saharan regions.

The following model show the interaction between agricultural growth and economic growth

$\mathrm{AgQ}=\mathrm{f}\left(\mathrm{R}, \mathrm{Fx}_{\mathrm{x}}, \mathrm{CAg}\right)$

NonX $=f(F x, C A g)$

$\mathrm{GRDP}=\mathrm{f}(\mathrm{R}, \mathrm{Fx}, \mathrm{CAg})$

Equation (1) is a theoretical equation, which states that agricultural output growth $(\mathrm{AgQ})$ is a function of interest rate (R), Exchange rate $(\mathrm{Fx})$ and credit to the agricultural sector $(\mathrm{CAg})$. Equation (2) theoretically states that non-oil export (NonX) is a function of exchange rate, credit to agriculture.. Equation 3 is the growth rate of GDP (GRDP), it is hypothesized that GRDP is a function of interest rate, exchange rate and credit to agriculture. It is important to note the problem of aggregation in this equation (3) because we are using a part to explain the whole. The problem could be solve if we used the percentage of agricultural credit to total credit (PCAg) and the percentage of NonX to total export (PNonX). Equation 3 changes to

GRDP $=\mathrm{f}(\mathrm{R}, \mathrm{Fx}, \mathrm{PCAg}, \mathrm{PNonX})$

Equations 1, 2 and 4 can be operationalised for the purpose of estimation into the following equations

$\operatorname{Ln} \operatorname{AgQ}=\mathrm{a} 0+\mathrm{a} 1 \operatorname{LnR}+\mathrm{a} 2 \mathrm{LnFx}+\mathrm{a} 3 \operatorname{LnCAg}+\mathrm{a} 4 \operatorname{LnAgQt}-1+\mathrm{ut}$

Ln NonX = b0 + b1 LnFx + b2 Ln CAg + b3 LnNonXt-1 + Vt .. (6)

$\operatorname{Ln}$ GRDP $=$ c0 + c1 LnR + c2 Ln Fx + c3 LnPCAg + c4 LnPNonX + lnGRDPt-1 + bt ... (7)

The above equations are transformed into log linear to facilitate easy estimation; we introduced lagged variables to indicate that the model is in a continuous process of adjustment and finally incorporate an error term, which is common to all econometric models given that by their nature, they are non-deterministic. 
The behavioural assumptions, the a priori, or the presumptive signs are stated as follows. a1 $\mathrm{c} 1,<0, \mathrm{~b} 1, \mathrm{a} 2, \mathrm{c} 2><0, \mathrm{a} 3, \mathrm{a} 4, \mathrm{~b} 2, \mathrm{~b} 3, \mathrm{c} 3, \mathrm{c} 4 \mathrm{c} 5>0$ while ut, vt and bt are expected equals to zero. Specifically, interest is negatively related to output while exchange rate is ambiguously related to output. Credit lagged values of the dependent variables are directly related to outputs.

\subsection{Method of Estimation}

The method of estimation for this study employed three stages least square analysis; the first is that, we estimate equations 1,2 and 4 using a three stage least square estimation technique, this is because the models are over identified. Secondly, we derived the historical simulation from the dynamic series to see how the macro-econometric models track the actual series. This is important for counter-factual analysis and to see if the models effectively evaluate the structure of agricultural production in the economy. Thirdly, we generate a policy simulation to discover the alternative policies scenario. In particular, we examine how changes in credit policy affect agricultural production, non-oil export and growth rate of GDP.

\section{THE RESULT ANALYSIS}

This section discusses the result for the study. All the diagnostic tests were generally satisfactory in all the estimated equations 8, 9 and 10. For example, the coefficient of determination and the adjusted coefficient of determination for all the equations range from 89 and 88 percent to 97 and 96 percent in all the estimated models. The f-statistics in all the equations are significant at the one percent level of significant and the Durbin Watson (DW) test show the absence of autocorrelation in all the models. This shows that the models are highly dependable.

$$
\begin{aligned}
& \operatorname{LnAgQ}=18.74-0.19 \mathrm{R} 0.11 \mathrm{CAgQ}+0.16 \mathrm{AgQt}-1
\end{aligned}
$$

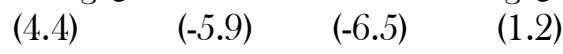

$$
\begin{aligned}
& \text { R } 2=0.89 \quad \text { R }-2=0.88 \quad \text { D-W }=2.09 \quad \text { F }=60.5 \\
& \text { Ln NonX }=0.035+1.09 F x+0.004 \text { CAgQ }+0.04 \text { NonXt-1 } \\
& \text { (0.3) (22.0) (21.1) (18.9) } \\
& \text { R } 2=0.91 \quad \text { R-2 }=0.89 \quad \mathrm{~F}=193.5, \quad \mathrm{DW}=1.71 \\
& \text { Ln GRDP }=0.85+2.00 \mathrm{R}-2.71 \mathrm{Fx}+0.44 \mathrm{pCAgQ}+0.38 \mathrm{PNonX}+0.25 \mathrm{GRDPt} \\
& \begin{array}{llllll}
(0.2) \quad(2.3) \quad(-41.0) \quad(3.6) \quad(1.6) \quad(21.5)
\end{array} \\
& \text { R } 2=0.97, \quad \text { R-2 }=0.96, \quad F=295.8, \quad D_{w}=2.31
\end{aligned}
$$

In equation (8), all the presumptive signs were correct apart from the level of credit to agriculture, which shows a negative sign instead of the positive sign. The t-statistic below each of the equation is significant at the one percent for interest rate and lagged value of the dependant variable. In equation (9), all the presumptive sign are correctly signed and the t-statistics were all significant at the one percent level of significance. In equation (10), all the variables apart from interest rate are all correctly signed. Interest rate, percentage of agriculture credit to total credit and percentage of non-oil export to total export are significant of at 5 percent level of significant. While exchange rate and lagged value of the dependant variable are significant at 1 percent level of significance. 
Table 1: Models Evaluation

\begin{tabular}{|l|l|l|l|l|l|}
\hline Model & $\begin{array}{l}\text { Correlation } \\
\text { Coefficient }\end{array}$ & $\begin{array}{l}\text { Root mean } \\
\text { square error }\end{array}$ & $\begin{array}{l}\text { Root mean } \\
\text { square percent } \\
\text { error }\end{array}$ & \multicolumn{2}{|l|}{ Theil's Inequality coefficient } \\
\hline & & & & 1961 & 1966 \\
\hline $\begin{array}{l}\text { Agricultural output } \\
\text { growth }\end{array}$ & 0.87 & 3.54 & 0.21 & 0.031 & 0.071 \\
\hline Non-Oil Export & 0.99 & 0.02 & 0.013 & 0.001 & 0.011 \\
\hline GDP growth rate & 0.97 & 20.9 & 0.105 & 0.056 & 0.107 \\
\hline
\end{tabular}

A closer look at table 1 shows that the performance of the macro econometric model is satisfactory. For example, the agricultural output shows a correlation coefficient between actual and simulated series to be 0.87 while the root-mean-square simulated series gives 0.87 while the root-mean-square percent error is 21 percent. Theil's 1961 and 1966 are 0.031 and 0.071 . This calibrated between 0 and 1 ; the closer to zero the coefficient, the better the simulated series track the actual values. In both case the value is less than 1 percent. In the case of non-oil export and the GDP all the measure performed very well like the agricultural output.

The results suggest that as in most developing countries, agricultural credit is an effective instrument for counter-cyclical agricultural output, non-oil export and GDP stabilization in the Nigerian economy although the value of GDP fell at the end of the period indicating that, such policies deteriorate with time.

\section{CONCLUSION}

The study examined the determinants of agricultural credit on economic development. Measures aimed at increasing agricultural production were discussed and the relationship between agricultural development and economic growth were also discussed. The result shows that agricultural credit, interest rate exchange rates were all important in affecting aggregate output in Nigeria. The study recommends that agric credits should be extended for development of agricultural production because it has causality effect on economic growth. 


\section{REFERENCES}

1. Abayomi, O. (1997). The agricultural sector in Nigeria: The way forward. CBN Bullion, 21, 14-25

2. Adetiloye, K. A. (2012). Agricultural financing in Nigeria: an assessment of the Agricultural Credit Guarantee Scheme Fund (ACGSF) for food security in Nigeria (1978-2006). J. Economics, 3(1), 39-48.

3. Ahmad, M. (2007). The effects of AKRSP's micro-credit programme on agriculture and enterprise development in district Astore Northen areas implication for poverty alleviation. M. sc (Hons) Thesis, Deptt. of Agric. Econ. Agric. Univ. Peshawar, Pakistan.

4. Akinleye, S. O., Akanni, K. A., Oladoja, M. A. (2005). An appraisal of the Agricultural Credit Guarantee Scheme in Nigeria. Journal of Agricultural Management and Rural Development, 2, 51-58.

5. Ammani, A. A. (2012). An investigation into the relationship between agricultural production and formal credit supply in Nigeria. International Journal of Agriculture and Forestry, 2(1), 46-52.

6. Awe, A. A. (2013). Mobilization of Domestic Financial Resources for Agricultural Productivity in Nigeria. Australian Journal of Business and Management Research, 2(12), 01-07.

7. Ayegba, O. \& Ikani, D. I. (2013). An impact assessment of agricultural credit on rural farmers in

8. Castro, E. R., \& Teixeira, E. C. (2012). Rural credit and agricultural supply in Brazil. Agricultural Economics, 43(3), 293-302.

9. Child MN, 2008. The effect of a depressed economy on agricultural sector. Journal of African Studies, 3 (2): 152-167.

10. Chisasa, J. \& Makina, D. (2015). Bank Credit and Agricultural Output in South Africa: Cointegration, Short Run Dynamics and Causality. Journal of Applied Business Research (JABR), 31(2), 489-500.

11. Emeka, O. M. (2007). Improving the agricultural sector toward economic development and poverty reduction in Nigeria. CBN Bullion, 4, 23-56.

12. Gokal, V. \& Hanif, S. (2004). Relationship between inflation and economic growth. Economics Department, Reserve Bank of Fiji.

13. Hussain, A. \& Taqi, M. (2014). Impact of agricultural credit on agricultural productivity in Pakistan: An empirical analysis. International Journal of Advanced Research in Management and Social Sciences, 3(4), 125-139.

14. Iganiga, B. O. \& Unemhilin, D. O. (2011). The impact of federal government agricultural expenditure on agricultural output in Nigeria. Journal of Economics, 2(2), 81-88.

15. Izuchukwu, O. (2011). Analysis of the contribution of agricultural sector on the Nigerian economic development. World review of business research, 1(1), 191-200. Journal of Economics and Sustainable Development www.iiste.org ISSN 2222-1700 (Paper) ISSN 2222-2855 (Online) Vol.7, No.2, 2016142

16. Marc D, 2006. Non-oil export in developing countries: some policy issues. African Review, 7 (2): 7 19.

17. Obeta, M. E., 1992. Agricultural Credit in Nigeria: Performance at Farm Level. African Review of Money Finance and Banking, 173-184.

18. Olagunju, F. I. \& Babatunde, R. O. (2011). Impact of credit on poultry productivity in southwestern Nigeria. ARPN J. Agric. Biol. Sci, 6, 58-64. 
19. Olajide, O. T., Akinlabi, B. H. \& Tijani, A. A. (2012). Agriculture resource and economic growth in Nigeria. European Scientific Journal, 8(22), 103-115

20. Olomola, A. S. \& Yaro, M. (2015). Commercial Banks' Response to Government's Financial Stimulus for Improved Agricultural Financing in Nigeria.

21. Rahman, S., Hussain, A., \& Taqi, M.(2014). Impact of agricultural credit on agricultural productivity in pakistan: an empirical analysis.

22. Tasie, C. M. \& Offor, U. S. (2013). Effects of International Fund for Agricultural Development (IFAD) Credit Supply on Rural Farmers in Rivers State, Nigeria. Journal of Poverty, Investment and Development, 1, 65-70.

23. Zakaree, S.S. (2014). Impact of Agricultural Credit Guarantee Scheme Fund (ACGSF) on Domestic Food Supply in Nigeria. British Journal of Economics, Management \& Trade, 4(8), 1273-1284. 